\title{
The Interaction Between Landmine Clearance and Land Rights in Angola: a Volatile Outcome of Non-Integrated Peacebuilding
}

\author{
Jon D. Unruh \\ McGill University
}

\begin{abstract}
The current approach to peacebuilding by the international community is to focus on the priorities thought to be important to recovery, but this occurs in a largely non-integrated way. With these different endeavors largely isolated from each other in planning, analysis, implementation, and measures for success, little is known about how they interact and whether or not the aggregate effect contributes to, or detracts from durable peace. This is especially important for priorities which in some way interact with each other on the ground among a recipient population. Two of these priorities for recovery, landmine clearance and land rights, while taking place on the same lands at the same time, and for the same people, are regarded separately as crucial to postwar recovery, and their interaction has not yet been examined. This article looks at these two priorities for Angola, and finds in their interaction a number of ways in which they detract from durable peace. This is a result of, 1) the role of areas adjacent to mine contaminated locations, 2) land grabbing, 3) the actions and role of the State, 4) the problematic interaction between different sectors involved in recovery, 5) the ongoing return of refugee and internal dislocatees and their (re)settlement, and 6) the lack of awareness of land tenure issues on the part of 'mine action' organizations. Subsequent to an examination of these forms of interaction this article looks at possible ways forward, focusing on, 1) the derivation of a form of 'forced transparency' as a deterrent to land grabbing, 2) enhancing the utility of 'land release' within the mine action community, 3) linkage of the different sectors concerned with mine action and land rights, and 4) the role than donors of mine action can play.
\end{abstract}

Keywords: Landmines, land tenure, peacebuilding, Angola

\section{Introduction}

With the lessons learned from peacebuilding experiences now becoming widely known, efforts need to progress beyond the pursuit of individual peacebuilding priorities as separate endeavors after wars, toward greater integration of these. Such a need comes with the recent realization that, 1) success in one priority of peacebuilding can detract from another, 2) there can be unexpected and often volatile repercussions due to specific interactions between parts of separate peacebuilding priorities, and 3) peacebuilding priorities and their projects and policies, while derived and implemented separately and on their own merits, do in fact interact robustly with each other on the ground in a largely unplanned and unexamined manner. With the international community's understanding of 
peacebuilding having progressed significantly in recent years, there emerges the opportunity to examine certain problematic interactions between specific priority areas of peacebuilding in order to find ways to mitigate acutely negative outcomes at a minimum, and enhance the prospects for complementarity so that such interaction contributes to, instead of detracts from durable peace.

While priority areas for peacebuilding and recovery can vary with the country and the conflict, two that are widely recognized as critically important, are the clearance of landmines, and the reconstitution of land and property rights systems. This article examines the highly problematic interaction between these two priorities for postwar Angola, focusing specifically on how the ongoing landmine clearance effort underway in the country intersects with the land rights situation in the country which the government, with assistance from the international community, is attempting to stabilize.

The clearance of landmines ${ }^{1}$ in war-torn countries is thought to contribute significantly to peacebuilding and postwar recovery in very substantial ways. Mine clearance is needed to remove impediments to post conflict reconstruction and development; promote livelihood recovery; reduce poverty; assist in development cooperation between bilateral, multilateral and government programs; train ex-combatants and demobilized soldiers; reopen access to agricultural lands, health and educational facilities; and promote economic reintegration of areas, markets, and people (GICHD 2008).

At the same time the reconstitution of land and property rights systems in conflict scenarios is fundamental for the return of dislocated populations, restitution, agricultural recovery and food security, broad economic recovery, dispute resolution, and the ability to address volatile ethnic, tribal and religious claims and attachments to lands (e.g., Bruch et al 2009; Unruh 2009). The reconstitution of functioning land tenure systems is also thought to resolve an array of political problems associated with areas claimed vs. gained or lost in battle by different groups during a war (Banks 2007; Andre 2003; Unruh 2003, 2004). As well land rights problems are recognized as an important cause and catalyst for armed conflict (Bailliet 2003; Cohen 1993; Barquero 2004; Bruch et al 2009; Unruh 2009). For example, issues of ethnic cleansing, evictions, retribution, inequality in land and property, control over high value resources such as diamonds and timber, legal pluralism that favors some sectors of society over others, legal systems that are noninclusive or exploitive, and land-related grievances and animosities, are all significant contributors to conflict scenarios (DW 2005; Unruh 2004; Bruch et al 2009; Cohen 1993; Wiley 2003).

While landmine clearance and land rights involve the same lands, they are not connected in analysis, policy, planning, programming, implementation, or evaluation - and the

\footnotetext{
${ }^{1}$ Reference to landmines in this paper refers not only to traditionally recognized mines but also explosive remnants of war (ERW), and unexploded ordenance (UXO).
} 
Angola case is particularly illustrative of this. They do however interact quite robustly on the ground and among a recipient population in an unplanned and to date unexamined way, to produce very difficult outcomes, with some of these working significantly against peacebuilding. Such outcomes can be particularly problematic when their repercussions become violent in a fragile postwar context. This paper examines the interaction between these two peacebuilding priorities. Subsequent to a brief background of Angola and a description of methods, the paper describes the land tenure and landmine situations in the country, followed by an examination of their interaction. The paper concludes with recommendations as to how to configure the interaction between these priorities so that they act in a more complimentary manner in postwar recovery, as opposed to detracting from the effectiveness of both, as well as durable peace.

\section{Background and Methods}

When the latest conflict in Angola finally ended in 2002, much of the country's infrastructure was destroyed, approximately two million Angolans were close to starvation, four million were dislocated, and only about three percent of the country's arable land was farmed (FAO 2002; Foley 2007). Located in southwest Africa, Angola is the second largest exporter of oil on the continent, and the fourth largest exporter of diamonds in the world. Prior to the wars Angola was an exporter of food products. It was once the fouth largest producer of coffee in the world, and the third largest producer of sisal (Clover 2005). Presently much of the country's 14.5 million people are impoverished. The maternal mortality rate is one of the highest in sub-Saharan Africa, one in four children die before their fifth birthday, 70 percent of the population lives on less than two dollars a day, and the majority of the population lacks safe drinking water, sanitation, and access to basic health services (Foley 2007). Approximately 80 percent of Angolan farmers are subsistence agriculturalists producing little if any surplus, while two percent are commercial farmers with paid employees (Deve 2007). The country clearly has a long way to go in recovery from its devastating civil wars.

Fieldwork for this article was conducted in two phases, one in July of 2006 with a focus on postwar land tenure, and another in November of 2010 in which the focus was explicitly on the intersection between land tenure and landmines. In total $69 \mathrm{key}$ informant interviews were conducted in both single and group formats. Key informants included people from government at different levels; domestic and international NGOs specializing on land tenure, landmines, agriculture, and those working with smallholders; representatives of the UN and other international organizations, and a variety of domestic and international 'mine action`2 organizations. As well a review of Angolan laws pertaining to land and property rights was conducted, along with a literature review of

\footnotetext{
2 'Mine action' refers to a broad range of activities and organizations including national mine action authorities, centers, and NGOs; mine clearance operators, contractors and humanitarian organizations, as well as donors. The mine action industry is large, global, and requires a significant amount of funds, with one estimate putting the funding requirement at 2.78 billion between 2009 and 2019 .
} 
Angolan and other countries' experiences with landmines and land tenure. The research also draws on a workshop that focused specifically on the issue of land rights and landmines for the countries of Afghanistan, Bosnia and Herzegovina, Cambodia, Sri Lanka, South Sudan, and Yemen, as well as Angola. The research for this article was funded by the Geneva International Centre for Humanitarian Demining (GICHD) in late 2010, and the Canadian Social Science and Humanities Research Council (SSRHC) in 2006.

\section{Dislocatee return}

\section{The Land Tenure Situation}

The end to the war in Angola has led to a scramble for land, particularly in the fertile central highland areas and involving a variety of competing interests including, government, returning displaced smallholders, commercial entities, and migrants and settlers to new areas. The demobilization and (re)settlement of approximately 100,000 former UNITA (Uniao Nacional para la Independencia Total de Angola) insurgent combatants was accomplished over the course of three years with little apparent serious problem, and was carried out jointly by UNHCR (UN High Commissioner for Refugees) and the Angolan Ministry for Social Reintegration (UNHCR/MSR nd). The reintegration programme included surveys of areas for return where land appeared to be available in the provinces of Moxico, Zaire, Lunda Norte, Kuando Kubango, and Uige--with close to 70 percent of ex-combatant returnees settling in these locations (Figure 1) (UNHCR/ MSR nd; Foley 2007). Dislocatee return was facilitated by local village elders (Sobas) who allocated land for free to returnees at an average of about one hectare per household. While no document was provided to returnees, there is an indication that they are included in local customary tenure arrangements and laws regarding inheritance and dispute resolution (Foley 2007). The primary reason for the relatively rapid return of rural IDPs (internally displaced persons) to their areas of origin was the need to quickly reclaim land, given the likely prospect that it could be claimed by someone else (Cain forthcoming). The potential threats to the lands of returnees included encroachment by large land interests, including current fazenda ${ }^{3}$ landholders (Robson 2006).

However in spite of the swift return to areas of origin many dislocatees had left their family land as long as 30 years earlier and upon their return discovered that they had been bypassed or excluded from land inheritance practices--with inheritance the primary way to acquire land. As well, in many cases upon their return to home areas IDPs encountered an unfriendly reception by those who stayed and suffered during the war, resulting in numerous land disputes. Land disputes also became aggravated by the actions of well intentioned humanitarian groups who provided highly uneven assistance to the local population. The Angolan state had a very limited presence in the areas of resettlement, and the Angolan justice system was among the weakest institutions of the postwar government (Cain forthcoming). While the role of customary authorities in land matters

\footnotetext{
${ }^{3}$ Commercial farms who had their beginnings in the colonial era.
} 
had disintegrated significantly during the colonial rule and years of war, the return and resettlement of close to four million people provided a restored role for the customary leadership in attempting to manage land disputes and providing testimonial evidence about the historical land claims of families and their descendants (Cain forthcoming).

\section{Insecurity in land}

While two-thirds of the national population reside in rural areas they have very little land tenure security, and hence little inventive to invest in their lands which would provide for the much needed increase in food security (Clover 2005). Land expropriation and concentration of land holdings by colonial settlers was one of the primary reasons for the independence war, such that the war came to be equated with land rights (Cain forthcoming). At the end of the subsequent UNITA war in 2002 disputes over land increased in frequency with the return of large numbers of displaced persons to areas of origin, or their settlement in new locations or areas that they occupied during the long war. The lands which were fertile and had easy access to the urban market (and free from landmines) in particular became the subject of numerous and volatile disputes between residents, returnees, migrants, ex-combatants, government, and commercial interests (Cain forthcoming). During the country's four decades of armed conflict, land rights issues such as mass evictions, land grabbing, large-scale displacement and resettlement were primary features of the conflicts, as well as the independence period. As one of the primary reasons for the UNITA conflict, land rights continue to bedevil the country's recovery (Cain forthcoming). Currently there are numerous reports of land grabbing in rural areas with some indication that this could increase as rural infrastructure improves with the clearance of mines and road reconstruction.

A primary issue in Angola is that land is held under customary forms of tenure for the vast majority of the population, but all land legally belongs to the state according to statutory law. In rural areas this is complicated by the contested occupation vs. ownership of the former colonial fazendas and the 'farm blocks' from the independence socialist era. Both arrangements disintegrated at different times in the Angolan wars and the farms were then occupied by smallholders who in many cases considered them to be their ancestral lands. However the cadastres to which these lands were attached came to be used by the Angolan elite to title lands and use them for commercial purposes, speculation, or rent, evicting the smallholder occupants. This process is currently ongoing and is facilitated by the existence and wide use of a colonial era map of the fazendas, along with the colonial land registry. At the same time the country's cadastral and property rights records have not been updated in a systematic fashion since independence in 1975, and hence there is no accurate national level estimate of the amount of land that is public, private, communal, or informally held (Cain forthcoming). And while the country could benefit significantly from legal, administrative, and tenurial innovation, the government controls and constrains the political space within which land rights can be discussed. 
While there are a variety of land-related documents in the country that can be obtained through forms of occupation, purchase, claim, or recognition of occupation by local customary or state authorities, in reality only those who have gone through the lengthy, expensive, arduous and corruption ridden process of obtaining formal title to 'surface rights' from provincial government have any real legal status. The FAO (Food and Agricultural Organization, UN) has been working with the Angolan government since 1999 in the construction of what is intended to be a participatory and decentralized land management system, with the aim of enhancing food security (Deve 2007). The progress in deriving this system however is quite slow and it still has not been implemented.

\section{The postwar land law}

The Angolan government moved quickly to craft a new postwar land law. A draft of the new land legislation was released in July 2002, just a few months after the official end to the war; and in fact drafting of the law was underway in 2001 before the war ended. The role of a team of Portuguese lawyers in writing the new law certainly facilitated this time frame, and it was passed by parliament in 2004 as the 'Land Law and the Law of Territorial and Urban Management'. While the government did invite public consultation on the 2002 draft, population dislocation, food insecurity, and impoverization were still at wartime levels for the vast majority of the population, so it is difficult to see how such a call for consultation could have been realistic. This was particularly problematic given that the repeated failures of previous peace accords for the country had resulted in a great many dislocatees not believing the war was actually over, and adopting instead a 'wait and see' position before returning home. Since the 'consultation' took place prior to the return of dislocatees to their home areas, the consultation did not facilitate input with regard to how the new law intersected with the land problems that were emerging after the war. As a result the new law does not attend to the realities, needs, and problems of the Angolan population. The law is significantly weak in a number of ways with regard to smallholder rights, and favors commercial interests. Particularly problematic for smallholders is the requirement that all existing land occupants needed to register their land and obtain title within three years of the law's passage, after which those without titles would be deemed illegal. This was widely viewed as extremely unrealistic given the very low capacity of government, illiteracy among the smallholder population, and the lack of needed formal identification documents (Foley 2007). And while the three year period has now passed, the regulations for applying for title have still not been published (Cain forthcoming). In any case the state lacks the capacity to implement the new law and regulations in a transparent manner, leaving it open to abuse and the actual management of land disorganized (Cain forthcoming).

During the war there was an explicit acknowledgement of the validity of de facto occupation of land that had been acquired in good faith (Cain forthcoming). However despite the government's endorsement of the international 'good practice' of progrssively legally recognizing existing occupations so as to upgrade them over time into secure 
forms of rights ${ }^{4}$, nevertheless the land law stipulates the elimiation of all occupancy (usucapiao) rights where use and occupation were solidified over time (Cain forthcoming).

Overall the current land law has resulted in several important outcomes. First, the smallholder sector is left with scattered small holdings, with no prospect of legal expansion, and without legal access to fallow lands which have an important role in subsistence agriculture, livelihoods, and preventing land degradation (DW 2002). In the current land law, as in the previous one, the very weak acknowledgement of customary rights over land has not conferred tenure security nor prevented expropriation (Pacheco 2002). Second, the new law has increased the state's power to confiscate land for reasons of 'public use' which can then be given to large-scale commercial interests. Third, the law does not fundamentally deal with the underlying problems which initially contributed to the war. And fourth, while there are a few improvements in the 2004 land law, the land tenure system in the country continues to be confusing, disorganized, and unsuited to deal with the many complex land issues which have emerged after the war. There are numerous misalignments between the law and reality, and the law's actual implementation holds the prospect of causing many problems and potential conflicts (Cain forthcoming).

\section{The Landmine Situation}

\section{Landmines in the Angolan wars}

Throughout the decades of war in Angola landmines and other explosive devices were a primary weapon used by both the UNITA insurgency and the MPLA government (LM 2010). Landmines in the country have maimed approximately 80,000 people during and after the war. With about 2000 communities affected by mines, Angola is thought to be one of the most mined countries in the world, and the most mine contaminated country in sub-Saharan Africa (Foley 2007; GICHD 2008). Because for a certain period of time Angola was one of the superpower proxy wars, and oil funded the government and diamonds funded UNITA, both sides were able to access and afford a very wide variety of weapons and ordinance that are not often found in other developing country wars. There were a number of approaches to laying mines during the war, such that little real overall pattern emerges. Many were laid according to Soviet, American, Cuban, Swapo, and South African training, as well as the relatively ad hoc approach used by some UNITA forces. While the various trained militaries laid mines with clear objectives--such as the Cubans laying long swaths of mines in the south of the country to deter advancing South African forces, or the mining of roads and bridges to deter troop movement, or the mining of economic assets to prevent them from being accessed by the opposing side-other forms of mine laying was less organized.

\footnotetext{
4 The government of Angola supported this approach at the 1996 Istanbul Urban Forum
} 
Due to the history of mines in the country, their movement subsequent to their initial placement is common and ongoing. Mines and UXO are easily washed to new locations during the rains, and can be picked up by local inhabitants (and village 'deminers') and deposited elsewhere in rural areas so as to be rid of them, only to be encountered at a later date. As well mined roads and bridges are still a primary aspect of the landmine problem in the country. The LIS (Landmine Impact Survey) noted at the time it was produced in 2007, that roads blocked by landmines were a problem throughout the country, impacting Bie, Huambo, and Moxico provinces in particular. In this regard the clearance of secondary roads over the next four years, especially in the south of the country, is a reconstruction priority (LM 2010).

\section{Demining organizations}

The government of Angola is the primary mine action actor in the country. The responsibility for the coordination of the overall mine action sector resides with the National Intersectorial Commission for Humanitarian Demining (CNIDAH, or Comissao Nacional Intersectorial de Desminagem e Assistencia Humanitaria), which has offices in all 18 provinces. These offices determine annual priorities for demining based on input from NGO priorities, the LIS, provincial plans, and requests from community leaders (LM 2010). As well the government created INAD, the National Demining Institute, which is responsible for all demining at the operational level. The government also created the Executive Commission for Demining (CED) to manage the demining activities of INAD, the Angolan military (FAA), and the Office for National Reconstruction. Additional national demining operators include the Angolan Border Police, along with 38 commercial companies. The commercial demining companies engage in clearance of highly variable quality, and are primarily involved in the clearance of the numerous national reconstruction projects, all of which must be demined even if there is no evidence of mines or UXO. Even potential diamond fields need to be cleared. Demining local community land or, "humanitarian demining 5 is primarily the domain of the international demining NGOs in Angola. As of the end of 2009 the humanitarian demining capacity comprised five international NGOs with 62 teams and 562 deminers (LM 2010).

The different mine action organizations have different sequencing priorities. For example, some organizations may clear roads first, or only roads and related infrastructure, while other humanitarian deminers tend to focus on community lands. One humanitarian demining organization in Angola often goes beyond their task order to also clear neighboring community lands that they discover to be contaminated while fulfilling their initial order to clear roadways. On the other hand, commercial demining organizations in

\footnotetext{
5 The Angolan military does not allow the international mine action NGOs to clear mined areas or battle zones which are near military bases, even if the local civilian population is at great risk (LM 2010).
} 
the country clear just the task order and ignore adjacent problems even when they became aware of them.

\section{Degree of contamination}

The country continues to be heavily contaminated by landmines, and over 40 types of mines originating in 15 different countries have been found (LM 2010). All 18 of the country's provinces still contain mines, and the 2007 LIS identified 3,293 suspected hazardous areas (SHAs) in 383 of the country's 557 districts (LM 2010). The impacted communities represent approximately 2.7 million people (LM 2010). And while the mine action program has cost an average of $\$ 30$ - \$50 million per year since 2002 , the spatial extent and degree of residual mine and ERW contamination is not known with any degree of certainty, with different mine clearance operators having very different estimates, methodologies, and perspectives on the overall extent and location of the contaminated area (LM 2010). Significant numbers of previously unknown mined areas continue to be discovered and some demining operators believe that many contaminated areas have yet to be identified (LM 2010). Landmine Monitor (LM 2010) reports that in many cases the new areas and roads that are being reported as contaminated are being discovered only as people move into vacant areas where there had been no prior information regarding contamination. This movement of people includes newly returning refugees from Zambia and the Democratic Republic of the Congo, as well as movements from overcrowded urban areas to rural locations. In addition, with the expanding urban, peri-urban and community occupation of lands in different parts of the country, there is new use of certain lands that have long been unoccupied (LM 2010). In 2010, 31 new contaminated areas were discovered by demining organizations in the provinces of Bengo, Benguela, Bie, Huambo, Huila and Kuando-Kubango, Kwanza Sul and Malanje (LM 2010) (Figure 1). Part of the problem in knowing the extent of the remaining mined area is the lack of a functioning national mine action database. Due to capacity and organizational problems Angola is unable to report with accuracy the area that has been cleared annually, or state the magnitude of the current remaining contamination problem, such as the total number of SHAs, the number of communities that are impacted, and the estimated size of the overall contaminated area (LM 2010). The Landmine Monitor reports that if capacity is not improved significantly, it could take decades to resolve the contamination problem (LM 2010).

There is uncertainty as to whether Angola is still affected by remnants of cluster munitions. While their use in the war is confirmed, it is unknown when during the war period they were used or by who. There is some indication that only the Angolan Armed Forces deployed cluster munitions, as UNITA did not have access to aircraft during the conflict. One mine action NGO notes that the larger problem is UXO, which are widely scattered across certain areas and are of a very wide variety, having originated from a number of countries--China, the US, the Soviet Block, South Africa, Israel, and Eastern Europe. As well there are sporadic reports of new postwar use of anti-vehicle and 
antipersonnel mines, apparently by criminal groups (LM 2010). However the exact nature of their use is unreported.

\section{Land release}

With such imprecision in estimating the extent of mine contamination, there are in addition to newly discovered areas, many other areas that were designated as contaminated in the LIS, and in fact are not. In many cases such areas lie adjacent to mined locations. While the overall number and size of these areas is unknown, they are nevertheless still scheduled to be cleared, at considerable cost. A new approach coming from the international mine action community to handle such areas, quickly and at much lower cost, is called 'land release' .6 For land release in Angola, the proposed 7 procedure is that a demining organization works closely with the impacted community or nearby community to ascertain the nature and boundaries of the potential land release area. Once the demining organization has determined (through primarily in-depth social survey procedures), that the area is 'safe' and has completed its land release investigations, it interacts with government and the local community for official release and handover. This includes providing documentation, maps, and survey results that are given to the local government and-or directly to the relevant $\operatorname{Soba}(s)$ at the community level. The Soba(s) then allocate the released land to the local community. However frequently the land to be released is already occupied, or people move onto the land as soon as the deminers finish with their survey work. Such a process is not entirely smooth however. Customary systems can discriminate against women's ownership rights to land. Such that even if a mine action organisation intends to hand cleared land directly over to women, without change in the way local management systems operate, the objective can be difficult to achieve. This can be especially problematic because there are many more female headed households after a war

While the current LIS is well regarded by the humanitarian mine action organizations, some believe the areas the LIS notes as contaminated, are in fact exaggerated--making the land release approach of critical importance. But as a result of the lack of government

\footnotetext{
${ }^{6}$ Land release refers to a process for releasing land from being categorized as mined, due to new information that indicates that the area in question is in fact not contaminated. This includes: 1) a formal, well-documented, recorded and publicly disseminated process of investigation into the mine/explosive remnants of war problem; 2) well-defined and objective criteria for the reclassification of land, publicly disseminated; 3) a high degree of community involvement and acceptance of the decision-making process, and the public dissemination of this involvement, including locating any relevant still-displaced community members that will likely have claims or be part of the intended beneficiaries; 4) a formal publicly disseminated process regarding the handover of land prior to its release, involving local communities, intended beneficiaries, government representatives, etc.; 5) an on-going monitoring mechanism after the handover has taken place, particularly with regard to the fate of land rights, claims, and disputes (GICHD); and 6) a common set of terminology to be used when describing the process.
}

7 'Proposed' because the government still has no official policy regarding land release. While there is a government field manual on land release, it awaits approval and dissemination from CNIDAH (the government demining commission) (LM 2010). The mine action community in Angola knows of the manual, but it is not expected to be approved and disseminated in the near future. 
policy or official position on land release, the government does not use it. Certain international humanitarian demining organizations in the country however do use and are quite adept at land release. One organization reports an almost 10 fold increase in their efficiency by utilizing land release, and a large monetary savings by putting significant intensive effort into local community interaction in order to get a greatly enhanced understanding of the actual mine threat.

\section{Problems for peacebuilding}

Interaction between Land Rights and Landmines

The World Bank's 2009 report on The Environmental and Social Management Framework noted that problems with land access in Angola is a primary impact of landmines in the country. However mine action in Angola does not respond directly and purposefully to land rights issues. Not only is there general unawareness of land problems on the part of the mine action community, but there is also an assumption that since the state owns all the land, and very few people have any land related documents, there can be no land disputes. But while there are many land disputes, along with land grabbing, tenure insecurity and a host of other problems, mine action by itself does not appear to be a direct, exclusive, cause, or a direct solution to these. Rather, mine action is a part of a larger picture of government interaction with local communities and the land issues that emerge. What does emerge via the interaction are a host of problems that detract from peacebuilding in the country. The subsections below briefly describe some of the more important of these. Demining organizations indicate that when there are land conflicts that they are aware of connected with demining, it is usually between the owner and the current occupants, and the demining organization somehow gets caught up in the conflict. In such a case they feel they need to side with the owner if $\mathrm{s} /$ he has a title or other relevant documents to the land. Land conflicts in Angola can be complex and multifaceted, and because mine action organizations are not a clear party to a land dispute with a claim, or may observe disputes that emerge in their wake, it can be difficult for mine action or land rights NGOs to be able to untangle land conflicts as being tied specifically to land mines or mine action. This can be especially the case when mine action organizations may have had a role in aggravating land disputes, such as by releasing them from being 'frozen' due to mine presence, or act as an arm of the state to solidify the state's claim on lands, even inadvertently.

\section{The role of adjacent areas}

Subsequent to the UNITA war the many mine contaminated areas together with the country's destroyed infrastructure, isolated many returnee communities and put great pressure on uncontaminated land where social services and non-agricultural jobs were concentrated (HRW 2006). Land that is adjacent to mined roads or other contaminated areas represents a category of land issues (and a large amount of land) that still eludes understanding by many mine action organisations. Although this land is not contaminated, its status often changes dramatically once neighbouring areas are cleared and access is opened up. For example, in Angola agricultural land was, and often still is, 
'blocked' in many areas of the country due to mine contaminated roads and other access points. Blocked irrigated land is also a problem in a number of Angolan provinces. And while the clearance and opening of specific locations and small areas does not usually present major problems explicitly within those areas, opening access to larger areas that were blocked by such smaller contaminated areas can lead to numerous land disputes as a 'land rush' ensues for access, use, and claim by returnees and others. As these larger areas are unlikely to be included in post-clearance assessments, mine action organisations often remain unaware of problems for this category of land. ${ }^{8}$

\section{Land grabbing}

Land grabbing occurs with mine action playing either an inadvertent role, or in a potentially preconceived arrangement to expropriate land. Such that land which has been seized on paper then needs to be demined for the new owner, with the arrival of deminers the first time that a local community will learn that their land has been seized. One NGO demining organization noted that after they had cleared land in one case, the government rezoned the land for a government agricultural project, complete with housing.

The prospect of newly cleared land being seized is such that one international demining organization has piloted a 'task impact assessment' in Angola that is designed to assist in the selection of communities to ensure that mine clearance is followed by the effective use of cleared land (GICHD 2008). They also perform follow-up visits and surveys after clearance with the beneficiaries. But local communities can as well derive their own ways to deter land grabbing. In Angola's Kwanza Sul Province, a local community believed that the land mines on their land were 'protecting' the local population from being evicted, and hence were against their removal.

\section{The state}

The role of the state in various issues of the mine action - land rights nexus is important for several reasons. First, local communities are aware of the relationship between demining and land grabbing. As a result they know to approach international humanitarian demining organizations with their mine problems (instead of the state or commercial demining organizations) because they know that there is then little chance of the land being grabbed. Some humanitarian demining organizations respond to such requests with a special 'quick reaction team'. On the other hand mine action organisations that are seen to represent elite, government, or corporate interests have had their vehicles and equipment damaged or stolen. Such mine action organisations may be

\footnotetext{
8 In a related issue, landmines are a primary obstacle to the creation of the new Kavango Zambezi Transfontier Conservation Area, which is set to become the world's largest game park, occupying the border area between Angola, Botswana, Namibia, Zambia, and Zimbabwe. Over 130,000 elephants are currently prevented from moving through the park from Botswana. Full designation of the park and elephant release into the wider area will be held up until the area is free from landmines, and mine clearance in the area is now an ongoing effort (LM 2010).
} 
perceived as biased political actors, which can stem from their association with the military or government - which usually occupied one side in the war. Communities that were recently targeted through counter-insurgency warfare or victims of a repressive regime may be particularly wary of the intentions of mine action organisations affiliated with the military or government. In Angola the national demining organization is part of government, and it is clear when they arrive in an area to engage in mine action that they are doing so as part of government plans, many of which have resulted in land expropriation from local communities.

Second, an important land rights related effort by the Angolan government is the creation of rural and urban 'reserves' for resettlement of former IDPs and urban migrants. Because the state owns all land in the country according to statutory law, these reserves are established where the state believes they should be, and there can be conflicts with local communities who have longstanding or ancestral claims to such lands. And because these reserves are part of officially designated 'national reconstruction' they must therefore be demined even when there is no indication of the existence of mines. The problem with this form of demining emerges when the first time the local community learns that their lands have been designated as a reserve is when a demining organization arrives at the location to begin its initial survey of the area, resulting in considerable aggression on the part of the local community, and then a reaction by government. In such cases mine action organizations can be seen as engaged in land expropriation. There are cases where land designated as reserves for resettlement are demined, and then after clearance either the land ends up being used for a purpose other than the stated resettlement, or remains idle for a long period of time, leading the mine action organization that cleared it to wonder what the real situation is with the land, and what government plans for it actually are. Some mine action NGOs note that the many 'reserves' used for resettlement are essentially lands seized by government, which need to then be demined, thus acting to provide contracts to commercial demining companies, solidifying the state's claim on such lands. The original occupants of these lands can be given a small set of 'take-it-orleave-it' options to select from as compensation. These include either very small sums of money, a plot of land elsewhere, or a house in the new resettlement scheme when and if these become available. Such options sometimes satisfies the local population, and sometimes not. When they do not satisfy the community being displaced, there is essentially no option for dispute resolution with the state, and such conflicts do not end up in a court. For its part, CNIDAH notes that they are aware of government approaches to expropriating land for reserves and other purposes, and that the government to the extent possible wants to avoid conflict over land with local communities and so offers compensation (albeit poor) in good faith.

\section{Different sectors}

A distinct problem in dealing with the intersection of mine affected communities and land rights is that these two topics align neatly with two different types of NGOs and units within the UN, as well as programs and projects sponsored by the donor community, and 
government. Discussions with both mine action and land rights sectors indicated that there is very little if any purposeful, planned interaction between the two. The cases where mine clearance organizations in Angola do link up with other NGOs seems to take place only occasionally in the field at the local level, and not centrally or in any planned approach. Thus a mine action organization may link with other NGOs in a specific project area for follow-on development activities, usually in response to local needs and requests, as opposed to in response to a mandate from their respective headquarters. International humanitarian demining organizations in Angola appear freer to engage in such linkages than government or the many commercial demining organizations.

\section{Returnees}

Refugee and IDP return to their lands and properties abandoned due to the war was particularly affected by the presence of landmines. A report by Human Rights Watch in 2005 noted that people were returning to communities--on roads and bridges that were a target of mine laying--and resettling on heavily mined land. The UN indicated at the close of the war that only 30 percent of the rural areas of IDP return were considered 'fit' for resettlement by UN standards, and that the presence of landmines figured prominently in this determination. And while the Angolan government's legislation on resettlement after the war was based on the UN's Norms for Humanitarian Settlement, in practice the reality for IDP return is that they were (and are) usually left on their own. In one sense this was highly problematic given the lack of information returnees had regarding which areas were mined. The national demining organization INAD is aware that people are still trickling back to Angola from the adjoining countries, particularly in the south, and that this presents a difficulty in preclearance occupation and in determining what areas need to be demined depending on where the returnees intend to go. Mine action organizations in the country report that very often people take their chances with contaminated areas and farm and graze on them in spite of the presence of mines and UXO. Because such a return trickle can, in aggregate, involve a large number of people and take place over large and scattered areas, the land rights - landmine situation can be challenging. The UN reports that the number of people killed by landmines in Angola almost tripled in 2010, as road infrastructure reconstruction is coupled with ongoing refugee return and a lack of awareness as to where the danger zones are (ReliefWeb 2010).

\section{Awareness}

Most demining organizations in Angola are very unaware of the land problems they can leave in their wake. With very little capacity to deal with land issues, or even enough awareness to avoid land conflicts that they contribute to or cause, most demining organizations adhere quite strongly to their officially stated and much valued position of 'neutrality'. However such a position is hard to sustain in reality. Their de facto involvement in the domain of land rights is so robust that the stated position of neutrality emerges as a fairly incongruous. While a good part of this is simple unawareness, there are additional problematic aspects. Coupled with 'neutrality' are positions of, 'its up to the government to deal with land issues;' or with regard to the local community, 'its their 
land they know best how to solve their land problems'. But mine action organizations operate at the pleasure of the host government, and for such organizations to get directly involved in land issues would be fairly political. To stay operating in the country then means steering very clear of such political involvement.

Some NGO mine action organizations note that it is common for many more smallholders to end up actually using demined land than the intended number of beneficiaries. One demining organization reported that on one of their projects the number of intended beneficiaries was estimated at approximately 500, but a subsequent survey found close to 6000 people using the land. And while the demining organization took this as a sign of success in their mine action activities, they were unable to elaborate on any land rights issues associated with such an influx--most likely because they were not looking into such issues. But with such an influx it is doubtful that significant land rights issues did not emerge among the people involved.

\section{Conclusion:}

\section{Toward an Improved Interaction}

While there are several ways to improve the interaction between land rights and mine action, it is important to note that it cannot realistically be expected that mine action organizations would be able to directly and purposefully take on a significant volume of land rights issues or cases. Thus in order to move toward greater complementarity it is worthwhile to build on the aspects of mine action that already have a positive, if inadvertent, unappreciated, and underutilized effect, on land rights.

\section{Transparency as a deterrent to land grabbing}

Because of the intensive interaction between mine action organizations and local communities during clearing, but particularly during land release surveys, it becomes, or could become, widely known in government, the NGO community, and local and sometimes national civil society, who the intended beneficiaries are. Such that because all parties interested in the particular area are aware that it is widely known who the intended beneficiaries are, a 'forced transparency' effect is generated that can have a deterrence effect on land grabbing. This can particularly be the case when there is a follow-on survey done six months or a year after clearance, or if an NGO or donor follows up quickly with a local development project in the area. Beneficiary communities would be better off if mine action organisations providing clearance documentation would do so in a highly transparent manner so that land grabbing by elite interests are discouraged, made more difficult or thwarted, and community claims--and evidence for claims--are facilitated. Conversely insufficient transparency and communication failures can result in the perception that demining actors are a threat to local interests, and can facilitate land grabbing when a few know who the intended beneficiaries are. 


\section{Enhancing 'land release`}

During the fieldwork it became clear that there are two categories of land rights benefits connected to the land release practice that go unnoticed by both the mine action and the land rights communities. Both could be built upon and utilized to significantly enhance the interaction between land rights and mine action. The first, is that the areas most appropriate for land release are in many cases already occupied by those local community members who may have a claim to such lands, however informal these may be. This is beneficial in a land rights - mine action context in a couple of ways. Not only is it much easier and quicker to sort out who should get the released land, it is more difficult to grab land on which there are already claims and clear occupation when international deminers arrive to engage in land release procedures in the area-essentially acting to solidify inplace smallholder claims. As well, the likelihood of land disputes is less because a history (even a short history) of occupation has more than likely already resolved such issues, such that the solidification of current occupant claims via land release procedures can take place on largely undisputed land, making such claims that much stronger. These benefits apply to areas subject to land release more so than for lands the local community believes is actually mined. Thus an important aspect of the land release concept is that the areas that are most subject to release, are also the areas (in a mine affected communities context) where land rights are perhaps more easily solidified and protected by the land release procedures.

The second category of benefits is the provision of strengthened land rights by the substantial interaction between a mine action organization and the local community. The array of material provided through the delimitation and survey exercises as part of land release procedures can contribute significantly to the tenure security of local communities, when such exercises result in documentation provided to these communities. Such documentation provides clear evidence for occupation and use of lands, and while not title, does nevertheless carry weight, particularly when it is attached to an international NGO demining organization, due to their perceived role as objective third party or advocate for local communities. Thus a positive contribution toward increasing complementarity between land rights and mine clearance would be to enhance this community interaction and documentary material provision aspect of the land release process. It is broadly known in the land rights community that a very wide variety of documentary substantiation other than land-specific documents can and does provide increased tenure security for smallholder communities (e.g., Maganga 2003; McAuslan 2003; Okoth-Ogendo 2000; Toulmin and Quan 2000). Most of such documentation is not derived explicitly for purposes of land rights, but is nevertheless highly useful and widely used to support important aspects of land tenure, especially in socio-political settings where government land institutions, and fairness and rights protection are dysfunctional or problematic, as they are in Angola. Building on this aspect of land release would contribute to tenure security and protection of rights, allowing for a more solid documentary base for what UN Habitat promotes, the 'upgrading' of land rights based on 
existing evidence, instead of simply the 'occupation` of lands, which the current law works against.

\section{Sector linkage}

Greater linkage with non-mine action NGOs and donors is a significant opportunity to enhance complementarity. These do not necessarily need to be land rights NGOs, but any NGO that has a presence in an area to be cleared or released would be valuable in terms of engaging mine action beneficiaries on land that has been turned over or released to them. However, NGOs who do focus on land rights are valuable in providing specific advice to the mine action community, to local communities, and to government in terms of how to increase tenure security and defend rights to demined and released land. An important first step in this regard would be for mine action organizations to simply have a list of land rights NGOs and other NGOs active in their areas of operation whom they can call on for assistance.

\section{Donors}

An important aspect of communication regarding mine action is to simply let the donor community resident in the country know that specific areas have been cleared. Donor development efforts can often shy away from mine contaminated areas, preferring instead to pursue projects in uncontaminated areas where they are more apt to see success in their efforts. Notifying donors that areas are newly cleared would at a minimum discourage them from avoiding such areas. Development projects in newly cleared areas can provide the needed presence that can support land rights of local communities, and discourage land grabbing.

The donor-stated measure of success for mine action organizations is quite important and demining organizations pay very close attention to such measures. In this regard if 'casualty count' or 'number of mines removed' is the criteria for success, then mine action organizations will select areas where these measures can be maximized. However if livelihoods, poverty reduction, improved economic activity, or access to additional lands, are the focus or partial focus of the measure of success for mine action, then this would play a significant role in encouraging mine action organizations to engage more effectively with land rights issues.

\section{Enhanced peacebuilding}

Land rights and landmine clearance are two components of peacebuilding, which as currently derived and implemented, are viewed as separate, individual activities able to generate benefits independently, regardless of their status and pace of change relative to each other. Certainly part of the reason for this separation is disciplinary (e.g., civil engineering, vs. political science, vs. law, etc.), as well as the manner in which projects for reconstruction are derived, funded, and operationalized. And while their interaction on the ground can cause problems for the broader peacebuilding effort, as this article attempts to demonstrate, there are opportunities for positive interaction. While it may 
seem self evident that the different components of peacebuilding should operate in a complementary or synergistic manner, exactly how the many different components of peacebuilding do in fact interact among a recipient population is much less well known, and where important work remains, with Angola is a vivid example.

\section{Bibliography}

C. Andre, Custom, contracts and cadastres in north-west Rwanda, in T.A

Benjaminsen, C. Lund (Eds.), Securing Land Rights in Africa. London, CASS Publishing, 2003.

C. Bailliet, Property restitution in Guatemala: a transnational dilemma, in S. Leckie (Ed.), Returning Home: Housing and Property Restitution Rights of Refugees and Displaced Persons. Transnational Publishers, Ardsley NY, 2003.

P. Banks, Issues paper on reforming Liberia's legal and judicial system towards enhancing the rule of law. Governance Reform Commission, Monrovia, Republic of Liberia, 2007.

R. Barquero, Access to land in post-conflict situations: a case study in Nicaragua, UN Food and Agriculture Organization, Rome. 2004

C. Bruch, D. Jensen, M. Nakayama, J. Unruh, R. Gruby, R. Wolfarth, Post-conflict peacebuilding and natural resources, Yearbook of International Environmental Law 19 (2009) 58-96.

A. Cain, Angola: land resources and conflict, in: J. Unruh, R. Williams (Eds.), Land and Post Conflict Peacebuilding, Earthscan, (forthcoming)

J. Clover, Land reform in Angola; establishing the ground rules, in: C. Huggins, J. Clover (Eds), From the Ground Up; Land Rights, Conflict and Peace in Sub-Saharan Africa. African Centre for Technology Studies and the Institute for Security Studies, 2005.

S. Cohen, The Politics of Planting: Israeli-Palestinian Competition for Control of Land in the Jerusalem Periphery, University of Chicago Press, 1993.

F. Deve, Lessons learning in policy assistance, case study Angola, support to a decentralized land management programme, UN Food and Agriculture Organization, 2007.

Development Workshop (DW), TERRA urban land reform in post-war Angola. Development Workshop, Luanda, 2005. 
Development Workshop (DW), Land and reintegration of ex-combatants in post war Angola. Development Workshop, Luanda, 2004.

Development Workshop (DW), Study for a legal and institutional framework for improving land management in Angola — land management and land tenure in peri-urban areas. Luanda: Ministry of Urbanism and Public Works and the Ad-hoc Technical Group for Habitat, 2002.

C. Foley, Land rights in Angola: poverty and plenty, Humanitarian Policy Group Working Paper, Overseas Development Institute, London, 2007.

Geneva International Centre for Humanitarian Demining (GICHD), Linking mine action and development. GICHD, Geneva, 2008.

Geneva International Centre for Humanitarian Demining (GICHD), A Guide to Land Release: Non-technical Methods, Geneva International Centre for Humanitarian Demining, Publication No. 64, Geneva. http://www.gichd.org/en/gichd-publications/landrelease/?0, 2008.

Human Rights Watch (HRW), The responsibility to assist returnees. Human Rights Watch, New York, 2006.

Landmine Monitor (LM), Landmine and cluster munitions monitor - Angola. Landmine Monitor, http://www.the-monitor.org/custom/index.php/region_profiles/print theme/460 2010.

F. Maganga, The interplay between formal and informal systems of managing resource conflicts: some evidence from south-western Tanzania, in: T. Benjaminsen, C. Lund (Eds), Securing land rights in Africa, London: CASS Publishing. 2003.

P. McAuslan. Bringing the law back in: essays in land law and development, Ashgtate Publishing Limited, 2003.

H.W.O. Okoth-Ogendo, Legislative approaches to customary tenure and tenure reform in East Africa, in: T. Toulmin, J. Quan, (Eds), Evolving land rights, policy and tenure in Africa, London: Natural Resources Institute, 2000, 123-134.

F. Pacheco, The issue of land and agriculture in Angola, UN Food and Agriculture Organization, January, 2002

ReliefWeb, Landmine deaths triple in Angola in 2010: Halo Trust. UN-OCHA, 2010 
P. Robson (Ed), What to do when the fighting stops: challenges for post-conflict reconstruction in Angola, Development Workshop Occasional Paper No. 7, Luanda, 2006.

C. Toulmin, J. Quan, Registering customary rights, in: T. Toulmin, J. Quan (Eds.), Evolving land rights, policy and tenure in Africa, London: Natural Resources Institute, 2000, 207-228

UNHCR and Ministry for Social Reintegration (UNHCR/MSR), Sustainable reintegration programme in the major areas of return. Luanda, (not dated).

UN Food and Agriculture Organization (FAO) (2002) Charting Angola's Future. Newsroom, 22 April

J. Unruh, Land rights in postwar Liberia: the volatile part of the peace process, Land Use Policy 26 (2009) 425-433.

J. Unruh, Land tenure and legal pluralism in the peace process, Peace and Change: A Journal of Peace Research 28 (2003) 352-376.

J. Unruh, Rural property rights in a peace process: lessons from Mozambique, in: B. Warf D. Janelle, K. Hanson K (Eds.), WorldMinds: 100 Geographical Perspectives On 100 Problems, Kluwer, 2004.

L. Wiley, Land rights in crisis: restoring tenure security in Afghanistan, Afghanistan Research and Evaluation Unit, Kabul. 2003. 